\title{
Effect of Brand Communication and Experience on Loyalty: Mediating Effect of Brand Satisfaction and Trust. (Case Study of Customers of Inul Vista Karaoke, Semarang, Central Java, Indonesia)
}

\author{
Mr. Ngatno \\ Doctoral Program of Social Science \\ Diponegoro University, Semarang Indonesia
}

\begin{abstract}
This study examined the influence of brand communication and experience on brand satisfaction, trust and loyalty. The sample of this study was customer of "Inul Vista Karaoke" in Semarang, Central Java, Indonesia. 220 questionnaires were distributed with 95,91\% response rate. The data were analyzed using Partial Least Square (PLS). The results reveal that: a) brand communication and experience have a positive effect on brand satisfaction and trust. b) Brand communication is not direct effect on brand loyalty but brand experience is. c). Brand satisfaction and trust shows partially mediates beetwen brand experience and loyalty, and fully mediates beetwen brand communication and loyalty. The findings offer insight for Inul Vista Karaoke to increase loyalty must to be more increase brand experience than brand communication.
\end{abstract}

Keyword: brand communication, brand experience, brand satisfaction, brand trust, brand loyalty

\section{INTRODUCTION}

Currently in Indonesia many emerging karaoke entertainment service businesses. Many stand karaoke places that do not provide services in accordance with the expectations of consumers. On the other hand the number of karaoke entertainment venues that arise can be able to contribute revenue to the local government. Therefore this karaoke entertainment business as one of the creative industries need to be developed. For that to know the level of customer satisfaction and loyalty as the basis for coaching and development. This business is one of the services business, where management should be based on experiential marketing. The increase of offerings to customers and the rise of competition have made it harder for organisations to differentiate themselves solely by providing services that satisfy customer needs. The companies, in order to have a competitive advantage, are pressured by both the market and their customers, to come up with experiences that stimulate their target's emotions and sensations.

Experiential marketing is an important trend in marketing thinking. Through several books and articles, Schmitt $(1999,2003)$ has developed the concept of Customer Experience Management (CEM), which he defines as the process of strategically managing a customer's entire experience with a product or company. Recently, brands have become more important for creating the value for their customers. Building consumer-brand relationship is very important for building a strong brand. In the hypercompetitive markets, building consumerbrand relationships is one of the most important critical successful factors to differentiate brands and to develop life time customer value. Marketing academics and practitioners have recognized that consumers looking for entertainment with a particular brand name or which 
are able to provide them with an experience that is unique and memorable. As a result, the concept of the brand experience has become attractive to marketers. Before consumers remember and experienced the brand, companies must communicate the brand to prospective customers.

\section{STATEMENT OF THE PROBLEM}

The development of consumer-brand relationship has been the focus of the theory of the brand in recent years. A brand acts as a mechanism that involves the buyer and seller in the consumer-brand relationship (Keller, 1987; Davis, Buchanan-Oliver, \& Brodie, 2000). The main input of this relationship is brand experience and communication, while the main output of this relationship is brand loyalty. The final stage consumer-brand relationship is a response to the brand in the form of brand loyalty. The consumer-brand relationship is formed by the consumer's experience and knowledge of the brand. The consumer-brand relationship depends on the successful establishment of brand satisfaction and trust. Therefore, satisfaction and trust the brand becomes an important mediator between communication and brand experience with the brand loyalty.

Previously, the subject of brand personality, trust, satisfaction and loyalty has been attracted marketing scholars. However, recently researchers and practitioners place more emphasis on brand experience (Brakus, Schmitt, \& Zarantonello, 2009). Research on consumer-brand relationships have been carried out both in the manufacturing industry and the service industry. But there are still very scarce research done on the object of karaoke entertainment industry in Indonesia. Therefore, this study is an empirical study focuses on how to build the consumer-brand relationship of the experience factor and brand communications from the customer perspective Inul Vista karaoke in Semarang, Central Java, Indonesia. The aim of this research is to investigate the concept of brand experience in Indonesia context. In this research, the author will test the impact of brand experience towards loyalty directly or indirectly via brand satisfaction and trust.

\section{LITERATURE REVIEW AND RESEARCH HYPOTHESES}

Brand satisfaction and brand trust is a construction which is very important in the relationship between brand communication, experience and loyalty in a relational context. Brand experience is the stimulation result of brand communication. With the brand experience this causes consumers want to repeat this experience. Brand communication and experience influence not only trust and satisfaction but also at future consumer loyalty. Consumers should be more likely to be directed to buy the brand again and recommend it to others and tend to not buy other brands (Oliver, 1980; Mittal \& Kamakura, 2001).

\section{Brand communication.}

Brands are important in the consumer markets. A brand is a combination of corporate behavior and values, the technical functionality and quality of products and the intangible promise the company instills in their products for customers. It is a combination of tangible and intangible attributes and seeks to create a positive connection with the customer in order to create incentive for customers to use the products of the company in the now and in the future. Brand is the very key to integrated marketing (Schultz, 1998). Brands communicate with stakeholders and the target audience on many different levels. The communication may sometimes be intrinsic and non-verbal, which means that it may be formed by e.g. the imagery and visual elements associated with the brand. At this point it is important to note that brands communicate all the time at every point of contact with the target market, whether the company realizes this or not. Because of the communicative nature of brands, it is highly 
important to realize this in order to provide an accurate communication of the brand promise and experience. Brand communication is the primary integrative element in managing brand relationships with customers and creates positive brand attitudes. The objective of brand communication has been to expose the audience to a brand, whereby the effect can be maximized in terms of increased awareness and higher recall, so that the customer will buy the brand which has the highest recall; and to satisfy the customer to the optimum level (Panda, 2004; Zehir, Şahin, Kitapçi, \& Özçahin, 2011). Before consumers remember and experienced the brand, companies must communicate the brand to prospective customers. Any exposure of communication for the brand will affect consumer responses, which can be measured by analyzing variable brand awareness in terms of recall and recognition, favorability, strength and uniqueness of brand associations in consumer memory. The ability of brand names to evoke feelings such as trust, confidence and the like. Brand names should not be overlooked as a valid and useful avenue of communication in the creation of brand attitudes (Grace \& O'Cass, 2005). Several previous studies have shown that direct brand communication can influence consumers' satisfaction for a brand (Crosby \& Stephens, 2013; Zehir et al., 2011) and brand trust (Şahin, Kitapçi, \& Zehir, 2013). To summarize above mention, the research hypothesis is proposed as below:

Hypothesis 1: Brand communication has a positive effect on : (a) brand satisfaction, (b) brand trust, and (c) brand loyalty.

\section{Brand Experience.}

Consumer and marketing research has shown that experiences occur when consumers search for products, when they shop for them and receive service, and when they consume them (Brakus, et al.,2009). Consumers seeking not only functional benefits of a brand but also emotional experiences. Because the experience of using the product can provide value to consumers, it will affect consumer behavior to keep using it or not. Therefore, if consumers have a positive experience on a brand product then they will continue to use and if the consumer has a negative experience it will move to other brands. Brand experience is conceptualized as sensations, feelings, cognitions, and behavioral responses evoked by brandrelated stimuli that are part of a brand's design and identity, packaging, communications, and environments. Brand experience can be defined as the perception of the consumers, at every moment of contact they have with the brand, whether it is in the brand images projected in advertising, during the first personal contact, or the level of quality concerning the personal treatment they receive (Alloza, 2008). Brand experience is conceptualized as subjective, internal consumer responses (sensations feelings, and cognitions) and behavioral responses evoked by brand-related stimuli that are part of a brand's design and identity, packaging, communications and environments. Brand experience conceptualization and scale development are very important for understanding and managing brand trust and loyalty concepts (Brakus et al., 2009; Walter, Cleff, \& Chu, 2013; Rehman, Ahmed, Mahmood, Shahid, \& Sciences, 2014). Brand experience can be positive or negative, short-lived, or long-lasting. Brand experience affects consumer satisfaction and loyalty directly and indirectly through brand personality associations. Morever, brand experience can positively affect consumer satisfaction and brand loyalty, as well as brand trust (Zarantonello \& Schmitt, 2010; Rehman et al., 2014). To summarize above mention, the hypotheses for this research are proposed as below:

Hypothesis 2: Brand experience has a positive effect on: (a) brand satisfaction, (b) brand trust, and (c) brand loyalty.

\section{Brand satisfaction.}

Satisfaction is defined as an affective response to purchase situation (Babin, B. J., \& Griffin, 1998; Bagozzi, Gopinath, \& Nyer, 1999; Bennett, Härtel, \& McColl-Kennedy, 2005; Anderson \& Narus, 1990). Satisfaction is a positive affective reaction to an outcome of a prior experience. 
The satisfaction derived and attitude formed as part of a prior experience (Ganesan, 1994). Satisfaction impacts on subsequent purchases (Oliver, 1980b), completing cyclical pattern (Rebekah Bennett et al., 2005). In addition it also has been found to lead to the long-term combination of relationships (DL Gladstein, 1984; Anderson \& Narus, 1990). Brand relationship quality can be defined as the degree to which the consumer views the brand as satisfactory partner in an ongoing relationship; it is the consumer's overall assessment of the strength of his or her relationship with the brand (Algesheimer, Dholakia, \& Herrmann, 2005). Satisfaction is necessary but not sufficient component of loyalty (Agustin \& Singh, 2005). However, satisfaction is an antecedent of brand loyalty, with increases in satisfaction leading to increases in brand loyalty (R. Bennett, Mccoll-kennedy, \& Coote, 2000; Rebekah Bennett et al., 2005; Bolton, 1998; Jones \& Suh, 2000). Although, the marketing literature admits the assumption that satisfaction is linked to loyalty, the earlier concept seems to explain consumers' buying habits including all of their consistent purchasing behaviors (Rebekah Bennett et al., 2005). Satisfaction with the preferred brand is one of the determinants of brand loyalty. Beside that, (Geyskens, Steenkamp, \& Kumar, 1999) found satisfaction to be an antecedent to trust. According to the research, trust as a effect of satisfaction. Therefore, the following hypotheses are proposed:

Hypothesis 3: Brand satisfaction has a positive effect on (a) brand trust and (b)brand loyalty.

\section{Brand trust.}

A brand is a sign of confidence for all activities of intangibles (intangible) that generates trust, and the human touch is not there, it can become a symbol of quality and assurance in building trust (Lane, 1993; Bart, Shankar, Sultan, \& Urban, 2005). The importance of building trust has been shown in maintaining links buyers with sellers (Amine, 1998; Morgan Robert, 1994; Bart et al., 2005; Agustin \& Singh, 2005). Trust can be defined as the consumer confidence that he could rely on the seller to provide the services promised, while the value of relational can be defined as the perception of consumers about the benefits versus the costs incurred in the maintenance of exchange relationships progress (Agustin \& Singh, 2005). Brand trust is defined as the willingness of the average consumer to rely on the ability of the brand to perform its stated function (Moorman, Deshpande, \& Zaltman, 1993). This definition spans the two general approaches. First, trust has been viewed as a belief, sentiment, or expectation about an exchange partner's trustworthiness that results from the partner's expertise, reliability, or expectation about an exchange partner's trustworthiness that results from the partner's expertise, reliability, or intentionality. Second, trust has been viewed as a behavioral intention or behavior that reflects a reliance on a partner and involves vulnerability and uncertainty on the part of trustee (Moorman et al., 1993). Trust is built up by believing in the reliability and honesty of one side to the other. Since trust establishes an important bond between brand and customers, it is one of the determinants of brand loyalty. Without the trust on brand customer can't enter in loyalty set. To build a trust it's important for the Consumer to take and asses the information from the product. The brand trust of a product bought can be seen as the influence of credibility that can strengthen the purchasing behavior of consumers (Amine, 1998). Brand trust leads to brand loyalty or commitment because trust creates exchange relationships that are highly valued (Morgan Robert, 1994; Chaudhuri \& Hoibrook, 2001). While, commitment has been defined as "an enduring desire to maintain a valued relationship" (Moorman et al., 1993). Therefore, loyalty or commitment underlies the ongoing process of continuing and maintaining a valued and important relationship that has been created by trust. In other words, trust and commitment should be associated, because trust is important in relational exchanges and commitment is also reserved for such valued relationships. In this connection, explained that trust leads to commitment (Moorman et al., 1993; and Morgan Robert, 1994). Thus, we suggest that brand trust will contribute to brand 
loyalty. According to the research, trust and satisfaction show a significant positive correlation. Therefore, the following hypotheses are proposed:

Hypothesis 4: Brand trust has a positive effect on brand loyalty.

\section{Brand loyalty.}

Loyalty, as defined by Oliver (1997), is "a deeply held commitment to rebut or repatronize a preferred product/service consistently in the future, theory causing repetitive same-brand or same brand-set purchasing, despite situational influences and marketing efforts having the potential to cause switching behavior" (Chaudhuri \& Hoibrook, 2001). In marketing literature the term loyalty has often been used interchangeably with its operational (measurement) definition to refer to; repeat purchase, preference, commitment and allegiance. In addition, loyalty has been referred to in a variety of market-specific contexts, for example, service, store and vendor loyalty, an contexts that reflect the unit of measurement; customer and brand loyalty (Algesheimer, et al., 2005). One of the first definitions of brand loyalty was given by Jacoby \& Kyner, 1973: "the biased (i.e., non random) behavioural response (i.e., purchase) expressed over time by some decision making unit with respect with one or more alternative brands out of a set of such brands, and is a function of psychological (decision-making, evaluative) process". In research and literature, it would seem that two major approaches predominate. Attitudinal loyalty is often understood as a systematically favorable expression of preference for the brand (Dick, A.S. and Basu, 1994) and behavioral loyalty typically infers the loyalty status of a given consumer from an observation of repeated purchasing behavior (Kahn, B.E., Kalwani, M.U., \& Morrison, 1986). Brand loyalty may be indicated by brand attitudes and habit (Jacoby \& Kyner, 1973), it is also conceptually distinct from either attitudes or habits. It is widely considered that loyalty is one of the ways with which the consumer express his/her satisfaction with the performance of the product or service received (Bloemer, and Kasper, 1995; Delgado-Ballester \& Munuera-Alemán, 2001).

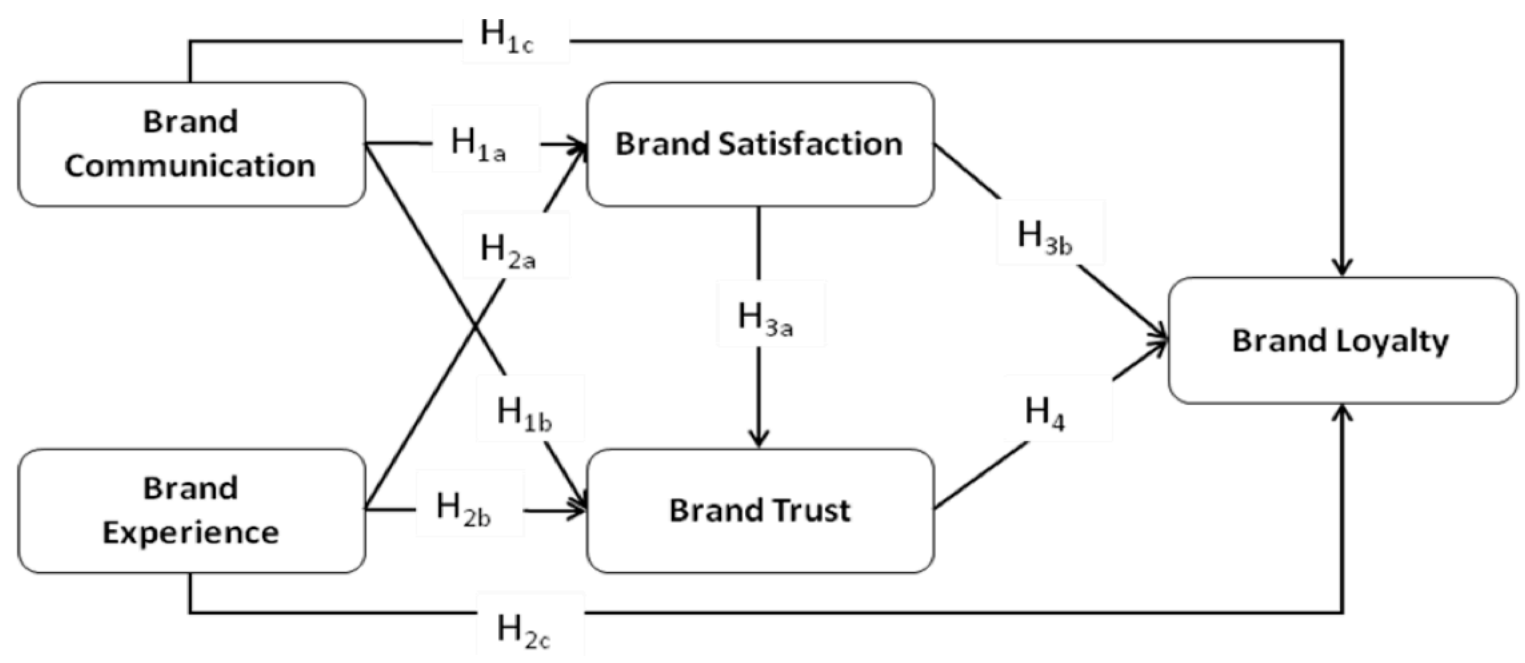

Figure 1: Conceptual Framwork

Brand loyalty is a prerequisite for a firm's competitiveness and profitability (Reichheld, F. F., Markey, R. G., and Hopton, 2000). Every firm desires to have its brands with high customer loyalty. Unfortunately, all brands cannot attract high loyalty. The development and maintenance of consumer brand loyalty is placed at the heart of companies' marketing plans, especially in the face of highly competitive markets with increasing unpredictability and reducing product differentiation (Fournier \& Yao, 1997; Fournier, 1998). The research model in Figure 1 posits the brand communication and experience build brand loyalty through brand trust and satisfaction. 


\section{Measures.}

\section{METHODE}

The constructs in our study were developed by using measurement scales adopted from prior studies. Modifications were made to the scale to fit the purpose of the study. All constructs were measured using five-point likert scales with anchors strongly disagree $(=1)$ and strongly agree $(=5)$. The brand communication measures were adopted from previous studies (Grace \& O'Cass, 2005; Yi \& La, 2004). The brand experience measures were adapted from previous studies (Brakus et al., 2009; Şahin, Zehir, \& Kitapçi, 2011). The brand satisfaction measures were adapted from a variety of sources (Grace \& O'Cass, 2005; Garbarino \& Johnson, 1999; Heitmann, Lehmann, \& Herrmann, 2007; McAlexander, Kim, \& Roberts, 2003). The brand trust measures were adapted from a variety of sources (Chumpitaz Caceres \& Paparoidamis, 2007; Delgado-Ballester \& Munuera-Alemán, 2001; Chaudhuri \& Hoibrook, 2001). The brand loyalty measures were adapted from previous studies (Grace \& O'Cass, 2005; Algesheimer et al., 2005; Hess \& Story, 2005; ValarieA. ZeithamI, Leonard L Berry, 1996).

\section{Sample and data collection}

120 questionnaires were distributed to customers of Inul Vista Karaoke in Semarang, Indonesia. The participants were asked to complete the questionnaire with respect to their brand "Inul Vista". Finally, 211 respondents returned the questionnaire, of which 9 forms were so incomplete that they had to be deleted. The final number of usable cases was 211 .

\section{Description of the Respondents}

\section{RESULT AND DISCUSSION}

Table 1 presents the description of respondents. The respondents were asked to report their demographic information, including gender, age, marital status and education. Most respondents aged between 10 years to 20 years, married, and high school educated. 
Table 1: Description of the Respondents

\begin{tabular}{|c|c|c|c|}
\hline Variables & Classes & Frequency & Frequency Percentage \\
\hline \multirow[t]{7}{*}{ Age } & $<15$ & 0 & 0.00 \\
\hline & $15-25$ & 136 & 64.45 \\
\hline & $26-35$ & 52 & 24.64 \\
\hline & $36-45$ & 15 & 7.11 \\
\hline & $46-55$ & 7 & 3.32 \\
\hline & $>55$ & 1 & 0.47 \\
\hline & Total & 211 & 100.00 \\
\hline \multirow[t]{3}{*}{ Gender } & Women & 108 & 48.82 \\
\hline & Man & 103 & 51.18 \\
\hline & Total & 211 & 100.00 \\
\hline \multirow[t]{3}{*}{ Marital Status } & Maried & 70 & 33,18 \\
\hline & Single & 141 & 66,82 \\
\hline & Total & 211 & 100.00 \\
\hline \multirow[t]{5}{*}{ Educational level } & Primary school & 4 & 1,90 \\
\hline & High school & 122 & 57,82 \\
\hline & University & 33 & 15,64 \\
\hline & Graduate & 41 & 19,43 \\
\hline & Total & 211 & 100.00 \\
\hline
\end{tabular}

\section{Measurement Model.}

To concentrate the effect of variables in research dimensions, every research variables are operated with factor analysis. There are; five items for brand experience, five items for brand communication, six items for brand satisfaction, seven items for brand trust, and seven items for brand loyalty. The factor loadings of brand experience, communication, satisfaction, trust, and loyalty are seen in Table 2. The first one to check is "Indicator Reliability". It can be seen that all of the indicators have factor loading values that are much larger than the minimum acceptable level of 0.4 and close to the preferred level of 0.7 . Traditionally, "Cronbach's alpha" is used to measure internal consistency reliability in social science research but it tends to provide a conservative measurement in PLS-SEM. Given that the appropriate value for Cronbach's alpha is 0.7 (Cronbach, 1951), for the composite reliability is 0.7 (Nunnally, 1978) and for AVE is 0.5 (Fornel \& Larker, 1981). 
Ngatno (2017). Effect of Brand Communication and Experience on Loyalty: Mediating Effect of Brand Satisfaction and Trust. (Case Study of Customers of Inul Vista Karaoke, Semarang, Central Java, Indonesia). Archives of Business Research, 5(4), 55-67.

Table 2: Results Summary for Reflective Outer Models

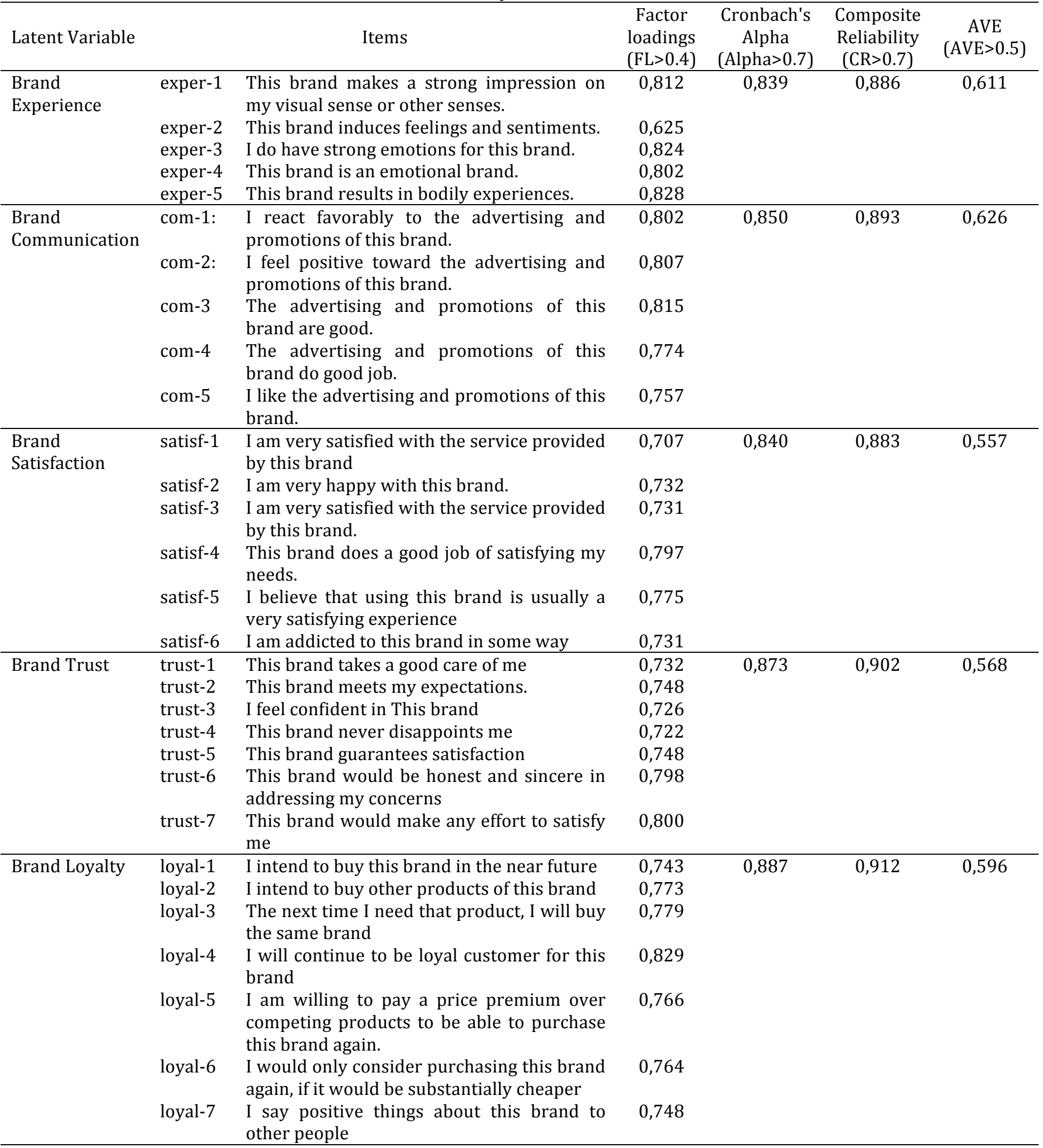

Results of the discriminant validity are provided by Larker Fornel"s method. Discriminant validity will compare the correlation of a component with its indices against its correlation with other components. Therefore, for reviewing this criterion, we use Larker Fornel"s matrix. In accordance with the table 3, the square roots of AVE (on the main diagonal), all components except the brand experience and loyalty component, are greater than the correlation between them. Therefore, the discriminant validity of the model is 
confirmed. In addition, load factor coefficients of all indices, according to table 2 . Since they are more than 0.40 , will be approved, and no indices will be removed.

Table 3: Discrimiant validity evaluation with Fornel Larker's method.

\begin{tabular}{lrrrrr}
\hline \multicolumn{6}{l}{ Table 3: Discrimiant validity evaluation with Fornel Larker's method. } \\
\hline Variables & $\begin{array}{c}\text { Brand } \\
\text { Communication }\end{array}$ & $\begin{array}{c}\text { Brand } \\
\text { Experience }\end{array}$ & $\begin{array}{c}\text { Brand } \\
\text { Loyalty }\end{array}$ & $\begin{array}{c}\text { Brand } \\
\text { Satisfaction }\end{array}$ & $\begin{array}{r}\text { Brand } \\
\text { Trust }\end{array}$ \\
\hline Brand Communication & $\mathbf{0 . 7 8 2}$ & & & & \\
\hline Brand Experience & 0.662 & $\mathbf{0 . 7 9 1}$ & & & \\
\hline Brand Loyalty & 0.621 & 0.790 & $\mathbf{0 . 7 4 6}$ & & \\
\hline Brand Satisfaction & 0.683 & 0.806 & 0.751 & $\mathbf{0 . 7 5 4}$ & \\
\hline Brand Trust & 0.644 & 0.725 & 0.746 & 0.754 & $\mathbf{0 . 7 7 2}$ \\
\hline
\end{tabular}

\section{Structural Model and hypothesis testing.}

The results of hypothesis testing for this study are shown in Table 4 . The first three research hypotheses deal with the direct impact of brand communication. Brand communication $(\beta=$ $0.265, \mathrm{p}=0.000$ ) is found to exert positive effect on brand satisfaction. Therefore, $\mathrm{H}_{1 \mathrm{a}}$ is supported. The result also showed that brand communication $(\beta=0.185, p=0.006)$ is positively effect on brand trust. Therefore, $\mathrm{H}_{1 \mathrm{~b}}$ is supported. Next, brand communication $(\beta=$ $0.046, \mathrm{p}=0.431$ ) is not significant effect on brand loyalty. Hence, $\mathrm{H}_{1 \mathrm{c}}$ is not supported. The second three research hypotheses deal with the direct effect of brand experience. Brand experience $(\beta=0.631, p=0.000)$ is found to exert positive effect on brand satisfaction. Therefore, $\mathrm{H}_{2 a}$ is supported. The result also showed that brand experience $(\beta=0.277, \mathrm{p}=$ 0.000 ) is positively effect on brand trust. Therefore, $\mathrm{H}_{2 b}$ is supported. Next, brand experience $(\beta=0.415, p=0.000)$ is significant effect on brand loyalty. Hence, $\mathrm{H}_{2 c}$ is supported. The third two research hypotheses deal with the direct effect of brand satisfaction. Brand satisfaction $(\beta$ $=0.166, \mathrm{p}=0.032$ ) is found to exert positive effect on brand loyalty. Therefore, $\mathrm{H}_{3 \mathrm{a}}$ is supported. The result also showed that brand experience $(\beta=0.405, p=0.000)$ is positively effect on brand trust. Therefore, $\mathrm{H}_{3 \mathrm{~b}}$ is supported. The last one research hypotheses deal with the direct effect of brand trust. Brand trust $(\beta=0.290, p=0.000)$ is positively effect brand loyalty. Hence, $\mathrm{H}_{4}$ is supported.

Table 4: Direct effect, indirect effect and total effect.

\begin{tabular}{|c|c|c|c|c|c|c|}
\hline \multirow[b]{2}{*}{ Path } & \multicolumn{2}{|c|}{ Direct effect } & \multicolumn{2}{|c|}{ Indirect effect } & \multicolumn{2}{|c|}{ Total effect } \\
\hline & $\begin{array}{c}\text { Path } \\
\text { Coefficient }\end{array}$ & P Values & $\begin{array}{c}\text { Path } \\
\text { Coefficient }\end{array}$ & $P$ Values & $\begin{array}{c}\text { Path } \\
\text { Coefficient }\end{array}$ & $P$ Values \\
\hline Brand Communication -> Brand Loyalty & 0.046 & 0.431 & 0.129 & 0.001 & 0.175 & 0.003 \\
\hline Brand Communication -> Brand Satisfaction & 0.265 & 0.000 & - & - & 0.265 & 0.000 \\
\hline Brand Communication -> Brand Trust & 0.185 & 0.006 & 0.107 & 0.000 & 0.292 & 0.000 \\
\hline Brand Experience -> Brand Loyalty & 0.415 & 0.000 & 0.259 & 0.000 & 0.674 & 0.000 \\
\hline Brand Experience -> Brand Trust & 0.277 & 0.000 & 0.255 & 0.000 & 0.532 & 0.000 \\
\hline Brand Satisfaction -> Brand Loyalty & 0.166 & 0.032 & 0.117 & 0.001 & 0.283 & 0.000 \\
\hline Brand Satisfaction -> Brand Trust & 0.405 & 0.000 & - & - & 0.405 & 0.000 \\
\hline Brand Trust -> Brand Loyalty & 0.290 & 0.000 & - & - & 0.290 & 0.000 \\
\hline
\end{tabular}

The next analysis address the indirect effect of brand communication and experience on brand loyalty, through brand satisfaction and trust (See Table 4). Firstly, the bootstrapping result for an indirect effect of brand communication on brand trust $(\beta=0.107)$ was significant $(p=$ $0,000)$. Hence, we can conclude that brand satisfaction act as mediator between brand communication and trust. While the direct effect of brand communication on brand trust 0.185 to $\mathrm{p}=0.006$, therefore, brand satisfaction partially mediates the relationship between brand communication and brand trust. Secondly, the bootstrapping result for an indirect effect of 
brand communication on brand loyalty $(\beta=0.129)$ was significant $(p=0,001)$. Hence, we can conclude that brand satisfaction and brand trust act as mediator between brand communication and brand loyalty. While the direct effect of brand communication on brand loyalty $(\beta=0.046)$ was not significant $(p=0.431)$, therefore, brand trust and satisfaction fully mediates the relationship between brand communication and brand loyalty. Thirdly, the bootstrapping result for an indirect effect of brand experience on brand loyalty $(\beta=0.259)$ was significant $(p=0,000)$. Hence, we can conclude that brand satisfaction and brand trust act as mediator between brand experience and brand loyalty. While the direct effect of brand experience on brand loyalty $(\beta=0.415)$ was significant $(p=0.000)$, therefore, brand trust and brand satisfaction partially mediates the relationship between brand experience and brand loyalty. Fourthly, the bootstrapping result for an indirect effect of brand experience on brand trust $(\beta=0.255)$ was significant $(p=0,000)$. Hence, we can conclude that brand satisfaction act as mediator between brand experience and brand trust. While the direct effect of brand experience on brand trust $(\beta=0.277)$ was significant $(p=0.000)$, therefore, brand satisfaction partially mediates the relationship between brand experience and brand trust. Lastly, the bootstrapping result for an indirect effect of brand satisfaction on brand loyalty $(\beta=0.117)$ was significant $(p=0,001)$. Hence, we can conclude that brand trust act as mediator between brand satisfaction and brand loyalty. While the direct effect of satisfaction on brand loyalty ( $\beta$ $=0.166)$ was significant $(\mathrm{p}=0.032)$, therefore, brand trust partially mediates the relationship between brand satisfaction and brand loyalty.

\section{DISCUSSION.}

The research was done using a theoretical framework developed based on previous studies. This paper has suggested what is possible, practical, and can be done by marketers in terms of brand communication, experience, satisfaction, trust and loyalty. Marketing managers can interpret these results as helping to justify expenditures on brand and customer related marketing activities that create such long-term effects on consumers as brand communication, experience, trust, satisfaction and loyalty. In this study, brand communication and experience is conceptualized as subjective consumer responses that are evoked by specific brand-related communicational and experiential attributes in such settings.

The study shows that brand communication has positive direct effects on brand satisfaction and trust. These findings are supported by some previous studies have shown that direct brand communication can influence consumers' satisfaction for a brand (Crosby \& Stephens, 2013; Zehir et al., 2011) and brand trust (Şahin, Kitapçi, \& Zehir, 2013). Brand communication creates and develops trust and satisfaction-based relationship platform between brand and customer. Instead of brand communication is no direct influence on brand loyalty, but brand communication can indirectly influence on brand loyalty through brand satisfaction and trust. While brand experience has positive direct effects on brand satisfaction, trust and loyalty. These findings are supported by (Brakus, et al.,2009), Zarantonello \& Schmitt, (2010), Rehman et al., (2014). Besides, the brand experience can be indirect effect on brand loyalty through brand satisfaction and trust. Further, brand satisfaction, trust and loyalty were primarily generated through brand experience rather than brand communication. These findings suggest that brand experience primarily impacts on brand satisfaction, trust and loyalty. Brand communication effect on brand loyalty was primarily indirect through brand satisfaction and trust. Our findings indicate that the brand experience is more important than the brand communication and indicated that brand communication had no direct influence on brand loyalty. Instead, understanding that brand communication plays an important role in maintaining and expanding market (especially for new buyers) should lead management to highly concentrate on avoiding actions that reduce in any way the credibility of the brand. The 
findings provide further encouraging evidence of the need to consider the brand experience affect and cognition in the development of brand loyalty. Loyalty is the overall level of contentment and pleasure resulting from experience with the service or product (Hellier, P., Geursen, G., Carr, R., \& and Rickard, J., 2003).

\section{Limitations and future research.}

This study has several limitations and also indicate directions for further research. The sample size itself is relatively small. By increasing the sample size and including participants in other geographical or subject areas, a more detailed empirical analysis among the independent variables and the variables that have multiple categories can be performed. The research indicates strong empirical support for the relationships among brand communication, experience, satisfaction, trust, and loyalty. In general, these findings should be replicated with different service categories and brands. Also, the present study did not examine personal factors, therefore we still need to develop a more detailed understanding of the relationship between brand loyalty and other related variables (especially antecedent variables: brand involvement, associations and personality). Overall, the more detailed understanding of the effects of brand communication, experiences, satisfaction, trust on building loyalty. Further research should focus on the antecedents and long-term consequences of brand experiences. Brand experience and communication dimensions evoked by brand related stimuli? In addition, direct and indirect brand experiences and communications should be explored, especially brand experiences affect customer lifetime value (Verena Vogel, Heiner Evanschitzky, \& B. Ramaseshan, 2000). Thus, how should marketers manage brands to create experiences that build such equity? (Brakus, et al., 2009).

\section{Refferences}

Agustin, C., \& Singh, J. (2005). Curvilinear effects of consumer loyalty determinants in relational exchanges. Journal of Marketing Research, 42(1), 96-108. http://doi.org/10.1509/jmkr.42.1.96.56961

Algesheimer, R., Dholakia, U. M., \& Herrmann, A. (2005). The Social Influence of Brand Community: Evidence from European Car Clubs. Journal of Marketing, 69(3), 19-34. http://doi.org/10.1509/ jmkg.69.3.19.66363

Alloza, A. (2008). Brand Engagement and Brand Experience at BBVA, the Transformation of a 150 Years Old Company. Corporate Reputation Review, 11(4), 371-379. http://doi.org/10.1057/crr.2008.31

Amine, A. (1998). Consumers' true brand loyalty: the central role of commitment. Journal of Strategic Marketing, 6(4), 305-319. http://doi.org/10.1080/096525498346577

Anderson, J. J. C., \& Narus, J. A. (1990). A model of distributor firm and manufacturer firm working partnerships. The Journal of Marketing, 54(1), 42-58. http://doi.org/10.2307/ 1252172

Babin, B. J., \& Griffin, M. (1998). The nature of satisfaction: An updated examination and analysis. JJournal of Business Research, 41(2), 127-136. http://doi.org/10.1017/ CB09781107415324.004

Bagozzi, R. P., Gopinath, M., \& Nyer, P. U. (1999). The Role of Emotions in Marketing. Journal of the Academy of Marketing Science, 27(2), 184-206. http://doi.org/10.1177/ 0092070399272005

Bart, Y., Shankar, V., Sultan, F., \& Urban, G. L. (2005). Are the Drivers and Role of Online Trust the Same for All Web Sites and Consumers? A Large-Scale Exploratory Empirical Study. Journal of Marketing, 69(4), 133-152. http://doi.org/10.1509/jmkg.2005.69.4.133

Bennett, R., Härtel, C. E. J., \& McColl-Kennedy, J. R. (2005). Experience as a moderator of involvement and satisfaction on brand loyalty in a business-to-business setting 02-314R. Industrial Marketing Management, 34(1), 97-107. http://doi.org/10.1016/j.indmarman. 2004.08.003

Bennett, R., Mccoll-kennedy, J., \& Coote, L. (2000). Trust , Commitment And Attitudinal Brand Loyalty : Key Constructs In Business-To-Business Relationships University of Queensland. ANZMAC 2000 Visionary Marketing for the 21st Century: Facing the Challenge, 88-92.

Bloemer, J.M.M. and Kasper, J. D. P. (1995). JoséM.M. Bloemer ,. Journal of Economic Psychology, 16(2), $311-329$.

Bolton, R. N. (1998). A Dynamic Model of the Duration of the Customer's Relationship with a Continuous Service Provider: The Role of Satisfaction. Marketing Science, 17(1), 45-65. http://doi.org/10.1287/mksc.17.1.45 
Ngatno (2017). Effect of Brand Communication and Experience on Loyalty: Mediating Effect of Brand Satisfaction and Trust. (Case Study of Customers of Inul Vista Karaoke, Semarang, Central Java, Indonesia). Archives of Business Research, 5(4), 55-67.

Brakus, J. J., Schmitt, B. H., \& Zarantonello, L. (2009). Brand Experience: What Is It? How Is It Measures? Does It Affect Loyalty? Journal of Marketing, 73(May), 52-68. http://doi.org/10.1509/jmkg.73.3.52

Chaudhuri, A., \& Hoibrook, M. B. (2001). The Chain of Effects from Brand Trust and Brand Affect to Brand Performance: The Role of Brand Loyalty. Brand, 65(April), 81-93. http://doi.org/10.1509/jmkg.65.2.81.18255

Chumpitaz Caceres, R., \& Paparoidamis, N. G. (2007). Service quality, relationship satisfaction, trust, commitment and business-to-business loyalty. European Journal of Marketing (Vol. 41).

http://doi.org/10.1108/03090560710752429

Crosby, L. A., \& Stephens, N. (2013). Effects of Relationship Marketing on Satisfaction, Retention, and Prices in the Life Insurance Industry. Journal of Marketing Research, 24(4), 404-411.

Davis, R., Buchanan-Oliver, M., \& Brodie, R. J. (2000). Retail Service Branding in Electronic-Commerce Environments. Journal of Service Research, 3(2), 178-186. http://doi.org/10.1177/109467050032006

Delgado-Ballester, E., \& Munuera-Alemán, J. L. (2001). Brand trust in the context of consumer loyalty. European Journal of Marketing, 35(11/12), 1238-1258. http://doi.org/10.1108/ EUM0000000006475

Dick, A.S. and Basu, K. (1994). Customer loyalty: Toward an integrated conceptual framework. Journal of the Academy of Marketing Science, 22, 99-133.

DL Gladstein. (1984). Gladstein_Groups in Context: A Model of Task Group Effectiveness. Administratif Science Quartly, 29(4), 499-517.

Fournier, S. (1998). Consumers and Their Brands: Developing Relationship Theory in Consumer Research. Journal of Consumer Research, 24(4), 343-353. http://doi.org/10.1086/209515

Fournier, S., \& Yao, J. L. (1997). Reviving brand loyalty: A reconceptualization within the framework of consumerbrand relationships. International Journal of Research in Marketing, 14(5), 451-472.

http://doi.org/10.1016/S0167-8116(97)00021-9

Franzen (1999), Brands \& Advertising: How Advertising Effectiveness Influences Brand Equity, Admap Publications, Henley-on-Thames.

Ganesan, S. (1994). Determinants of long-term in buyer-seller orientation relationships. Journal of Marketing, 58(2), 1-19. http://doi.org/10.2307/1252265

Garbarino, E., \& Johnson, M. S. (1999). The different roles of satisfaction, trust, and commitment in customer relationships. Journal of Marketing, 63(2), 70-87. http://doi.org/ 10.2307/1251946

Geyskens, I., Steenkamp, J.-B. E. M., \& Kumar, N. (1999). A Meta-Analysis of Satisfaction in Marketing Channel Relationships. Journal of Marketing Research, 36(2), 223-238. http://doi.org/10.2307/3152095

Grace, D., \& O'Cass, A. (2005). Examining the effects of service brand communications on brand evaluation. Journal of Product \& Brand Management, 14(2), 106-116. http://doi.org/10.1108/10610420510592581

Heitmann, M., Lehmann, D. R., \& Herrmann, A. (2007). Choice Goal Attainment and Decision and Consumption Satisfaction. Journal of Marketing Research, 44(2), 234-250. http://doi.org/10.1509/ jmkr.44.2.234

Hellier, P., Geursen, G., Carr, R., \& and Rickard, J., (2003). Customer repurchase intention: A general structural equation model, European Journal of Marketing, 37(11), 1762 - 1800

Hess, J., \& Story, J. (2005). Trust-based commitment: multidimensional consumer-brand relationships. Journal of Consumer Marketing, 22(6), 313-322. http://doi.org/10.1108/ 07363760510623902

Hoek Janet Jason, Dunnett Malcolm, Wright Philip Gendall, (2000),"Descriptive and evaluative attributes: what relevance to marketers?", Journal of Product \& Brand Management, Vol. 9 Iss 6 pp. 415 - 435

Jacoby, J., \& Kyner, D. B. (1973). Brand Loyalty vs. Repeat Purchasing Behavior. Journal of Marketing Research, 10(1), 1-9. http://doi.org/10.2307/3149402

Jones, M. A., \& Suh, J. (2000). Transaction-specific satisfaction and overall satisfaction: an empirical analysis. Journal of Services Marketing, 14(2), 147-159. http://doi.org/10.1108/ 08876040010371555

Kahn, B.E., Kalwani, M.U., \& Morrison, D. G. (1986). Measuring Variety-Seeking and Reinforcement Behaviors Using Panel Data. Journal of Marketing Research, 23(2), 89-100. http://doi.org/10.2307/ 3151656

Keller. (1987). Keller Development Use of ARCS.pdf. Journal of Instructional Development, 10(3), 2-10.

Kempf, D.S., Smith, R.E. (1998), “Consumer processing of product trial and the influence of prior advertising: A structural modelling approach”, Journal of Marketing Research, Vol. 35, No. 3, pp. 325-338 
Lane, K. K. (1993). Conceptualizing , measuring , and managing customer-based brand equity. Journal of Marketing, 57(1), 1-22.

McAlexander, J. H., Kim, S. K., \& Roberts, S. D. (2003). Loyalty: the Influence of Satisfaction and Brand Community Integration. Journal of Marketing Theory \& Practice, 11(4), 1-11. http://doi.org/10.2307/ 40470114

Mittal, V., \& Kamakura, W. a. (2001). Satisfaction, repurchase intent, and repurchase behavior: investigating the moderating effect of customer characteristics. Journal of Marketing Research, 38(1), 131-142. http://doi.org/10.1509/jmkr.38.1.131.18832

Moorman, C., Deshpande, R., \& Zaltman, G. (1993). Factors Affecting Trust in Market Research Relationships. Journal of Marketing, 57(1), 81-101.

Moorman, Christine, Gerald Zaltman, and Rohit Deshpande (1992), "Relationships Between Providers and Users of Market Research: The Dynamics of Trust Within and Between Organizations," Journal of Marketing Research, 29 (August), 314-29.

Morgan Robert, H. S. (1994). The commitment-trust theory of relationship marketing. J Market, 58(July), 20-38.

Oliver, R. L. (1980a). A cognitive model of the antecedents and consequences of satisfaction decisions. Journal of Marketing Research, 17, 460-470. http://doi.org/10.2307/3150499

Oliver, R. L. (1980b). A Cognitive Model of the Antecedents and Consequences of Satisfaction Decisions. Journal of Marketing Research, 17(4), 460-469. http://doi.org/10.1017/ CB09781107415324.004

Panda, T. . (2004). Consumer Response to Brand Placements in Films Role of Brand Congruity and Modality of Presentation in Bringing Attitudinal Change Among Consumers with Special Reference to Brand Placements in Hindi Films. South Asian Journal of Management, 11(4), 7-26.

Rehman, A., Ahmed, M. A., Mahmood, F., Shahid, M., \& Sciences, A. (2014). The Effects of Brand Experience, Satisfaction and Trust on Brand Loyalty ; an Empirical Research on the Internet Services of Cellular Companies in Pakistan 2 . Significance of Study : 3 . Literature Review : International Journal of Management Sciences and Business Research, 3(9), 90-100.

Reichheld, F. F., Markey, R. G., Hopton, C. (2000). The loyalty effect: The relationship between loyalty and profits. European Business Journal, 12(3), 134-139.

Şahin, A., Kitapçi, H., \& Zehir, C. (2013). Creating Commitment, Trust and Satisfaction for a Brand: What is the Role of Switching Costs in Mobile Phone Market? Procedia - Social and Behavioral Sciences, 99, 496-502. http://doi.org/10.1016/j.sbspro.2013.10.518

Şahin, A., Zehir, C., \& Kitapçi, H. (2011). The effects of brand experiences, trust and satisfaction on building brand loyalty; an empirical research on global brands. Procedia - Social and Behavioral Sciences, 24, 1288-1301. http://doi.org/10.1016/ j.sbspro. 2011.09.143

Schmitt, B. H. (1999), Experiential Marketing. Journal of Marketing Management, 15, 53-67.

Schmitt, B. (2003). Customer experience management: A revolutionary approach to connecting with your customers. New York: Wiley.

Schultz, W. (1998). Predictive reward signal of dopamine neurons. Journal of Neurophysiology, 80(1), 1-27. http://doi.org/10.1007/s00429-010-0262-0

ValarieA. ZeithamI, Leonard L Berry, \& A. P. (1996). The Behavioral Consequences of Service Quality. Journal of Marketing, 60(April), 31-46.

Vogel V, Heiner Evanschitzky, \& B. Ramaseshan (2000). Customer Equity Drivers and Future Sales, Journal of Marketing Vol. 72 (November 2008), 98-108

Walter, N., Cleff, T., \& Chu, G. (2013). Brand experience's influences on customer satisfaction and loyalty: A Mirage in Marketing Research? International Journal of Management Research and Business Strategy, 2(1).

Yi, Y., \& La, S. (2004). What Influences the Relationship between Customer Satisfaction and Repurchase Intention? Investigating the Effects of Adjusted Expectations and Customer Loyalty. Psychology and Marketing, 21(5), 351373. http://doi.org/10.1002/mar.20009

Zarantonello, L., \& Schmitt, B. H. (2010). Using the brand experience scale to profile consumers and predict consumer behaviour. Journal of Brand Management, 17(7), 532-540. http://doi.org/10.1057/bm.2010.4

Zehir, C., Şahin, A., Kitapçi, H., \& Özçahin, M. (2011). The effects of brand communication and service quality in building brand loyalty through brand trust; the empirical research on global brands. Procedia - Social and Behavioral Sciences, 24, 1218-1231. http://doi.org/10.1016/j.sbspro.2011.09.142 